\title{
Effect of Gibberellic Acid, Cytofex, and Calcium Chloride as Pre-Harvest Applications on Storability of "Thompson Seedless" Grapes
}

\author{
U. K. El-Abbasy", S. M. Al-Morsi", Fatma E. Ibrahim ${ }^{* *}$ and \\ Maha H. Abd El-Aziez ** \\ *Department of Horticulture, Faculty of Agriculture, Tanta \\ University, Tanta and ${ }^{* *}$ Horticulture Research Institute, \\ Agricultural Research Centre, Cairo, Egypt.
}

\begin{abstract}
7 HIS INVESTIGATION was carried out to evaluate the effects of spraying two growth regulators, i.e. Cytofex (CPPU) at $6 \mathrm{ppm}$ and Gibberellic acid $\left(\mathrm{GA}_{3}\right)$ at $20 \mathrm{ppm}$ two times (after fruit set and at $4 \mathrm{~mm}$ berries diameter) alone or in combination with calcium chloride $0.5 \%$ at berry veraison on "Thompson seedless" grapes quality during cold storage at $0{ }^{\circ} \mathrm{C}$ and $\mathrm{RH} 95-98 \%$. Cluster treated with Cytofex (CPPU) showed the lowest weight loss after 60 days of cold storage. Moreover, the clusters treated by Cytofex combined with $\mathrm{GA}_{3}$ and calcium chloride showed the highest weight loss during shelf life, higher berry removal force, the lowest percent of fruit decay and the highest marketable fruit. CPPU treatment and its combinations with $\mathrm{GA}_{3}$ and or $\mathrm{CaCl}_{2}$ showed the lowest Pectinmethylestraese activity after 60 days of cold storage. Clusters sprayed with $\mathrm{GA}_{3}+\mathrm{CaCl}_{2}$ showed the highest berry firmness after 60 days of cold storage. Clusters treated by calcium chloride at $0.5 \%$ and control showed the highest SSC: acid ratio. Moreover, it showed the highest total, reducing and non reducing sugars contents after 60 days of cold storage.
\end{abstract}

Keywords: Grapes, $\mathrm{GA}_{3}, \mathrm{CPPU}, \mathrm{CaCl}_{2}$, Cold storage, Storability, Quality.

Grapes (Vitis vinifera L.) is considered one of the most popular and common fruits in the world. In Egypt the area of grape vine increased recently and reached 171,973 feddan which produces 132,801 tons according to FAO, 2011. Thompson Seedless is the most popular cultivar of table grapes in Egypt, as well as the export market. Its marketing value depends upon its desirable appearance, berry and cluster size and shape. The use of Gibberellic acids $\left(\mathrm{GA}_{3}\right)$ is quite common in table grape production, where the impacts on grapes quality are mentioned. Gibberellins affect postharvest grape physical and chemical deterioration, especially berry dehydration because of vapor pressure deficit, skin browning, and changes in carbohydrates and phenols concentrations (Vial et al., 2005). Gibberellic acid $\left(\mathrm{GA}_{3}\right)$ as pre-harvest treatment was reached the highest fruit detachment force, markedly the lowest berry drop and improved berry firmness, delayed the decrease of soluble solids content (SSC) and vitamin C after stored at $0^{\circ} \mathrm{C}$ in $95 \%$ relative humidity for 60 days (Deng et al., 2006), and 
the lowest weight loss and effective in reducing decay percentage up to third week of storage of grapes (Meena et al. 2012). Forchlorfenuron (CPPU) was introduced to increase berry size. CPPU stimulates periclinal cell division in the berry, leading to be more round, but it also delays maturity and increases rachis size and pedicel thickness (Reynolds et al., 1992 and Retamales et al., 1995), increases berry shatter during storage (Navarro et al., 2001), but remained significantly berry firmness of Thompson Seedless grapes after cold storage (Ebisuda and Dokooglian, 2003) and decreased total soluble solids after cold storage or ambient stay periods. It reduced berry abscission after 30 days of refrigerated storage $\left(1^{\circ} \mathrm{C}\right)$ (Zabadal and Bukovac, 2006), and did not increase berry shatter (Zoffoli et al., 2009).

Calcium is an important constituent of plant tissues and has a vital role in maintaining and modulating various cell functions (Elad and Kirshner 1992). Physiologically, it is important in many fruits and vines. Spraying calcium chloride $\left(\mathrm{CaCl}_{2}\right)$ on Thompson Seedless grapevines increased berries firmness and decreased the percentage of unmarketable berries after keeping at ambient temperature for seven days after harvest (Marzouk and Kassem, 2011), and it reduced $B$. cinerea rots during storage (Ciccarese et al., 2013). Calcium chloride treatment decreased weight loss, shattering percentage and delayed the changes in firmness, titratable acidity, total soluble solids, vitamin $\mathrm{C}$, anthocyanin content and respiration rate during storage periods (Wafaa et al., 2014).

The objectives of this study were to evaluate the effectiveness of pre-harvest applications by Cytofex and Gibberellic acid alone or combined with calcium chloride on storability and quality during cold storage of "Thompson Seedless" grapes.

\section{Materials and Methods}

This study was carried out during the two seasons of 2012 and 2013 on seven years old, vigorous, fruitful "Thompson Seedless" (Vitis vinefera L.) grapevine. The study was conducted in a private vineyard located in El-Moatamadia in ELMahala El-Kobra, Gharbia Governorate. The vines were planted in loamy clay soil at 1.5 in row and $x 3$ meters between rows. The vines were head-trained and cane-pruned. The total number of eyes per vine ranged from 40 to 45 buds. Normal cultural practices as recommended by the Ministry of Agriculture and Land Reclamation for grapevines were done. Two hundred and sixteen to be healthy and as uniform as possible in both vigor and crop load vines were selected to be healthy and as uniform as possible in both vigor and crop load. The selected vines were divided into three plots, each treatment represented by nine vines in plot. The replicate was represented by three vines. The clusters sprayed by the following treatments: 


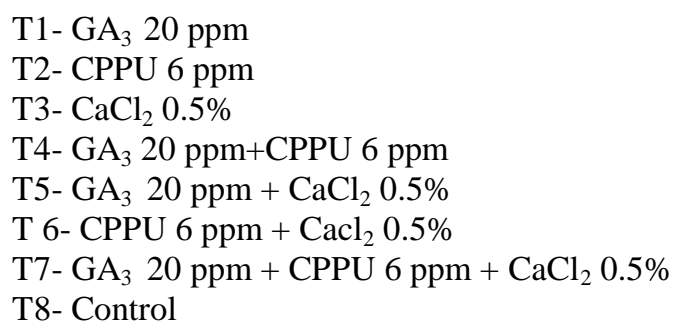

Gibberelic acid $\left(\mathrm{GA}_{3}\right)$ at $20 \mathrm{ppm}$ was sprayed at two times (after fruit set and again at $4 \mathrm{~mm}$ berries diameter), Forchlorfenuron (CPPU) $6 \mathrm{ppm}$ was sprayed at $4 \mathrm{~mm}$ berries diameter, Calcium chloride $\left(\mathrm{CaCl}_{2}\right)$ 0.5\% was sprayed at berry veraison and control ( sprayed with water at verasion). Clusters were picked after 117 and 122 days of full bloom in two seasons, respectively. At harvest time, clusters were picked early morning and transported within three hours at ambient temperature $\left(28{ }^{\circ} \mathrm{C} \& 75 \% \mathrm{RH}\right)$ to laboratory of Horticulture Res. Inst., El-Giza, Egypt. The clusters were packed in perforated carton boxes $(50 \times 35 \times 15 \mathrm{~cm})$, and slow- release $\mathrm{SO}_{2}$ pads were placed in carton boxes to control Botrytis decay during cold storage. $\mathrm{SO}_{2}$ pads were replaced with new ones every 15 days. All carton boxes were stored at $0{ }^{\circ} \mathrm{C}$ and $95-98 \% \mathrm{RH}$. Every treatment was represented by three carton boxes ( $4 \mathrm{~kg}$ of clusters per carton box as replicate) for every storage period. Each carton box contained three clusters were weighed and labeled at picking time to determination the cluster weight loss during the different cold storage periods.

At the picking date (zero time of cold storage) and after every 15 days up to 60 days of cold storage, samples of three carton boxes per treatment were taken out to evaluate the storability of Thompson seedless grape as affected by the preharvest treatments.

\section{The following parameters were measured \\ Physical properties}

Every 15 days of cold storage period up to 60 days, the labeled three clusters were reweighed after storage. The clusters weight loss was calculated as percentage related to the weight of the same clusters before cold storage. Three clusters from each replicate were weighed and kept in the ambient room temperature $\left(28^{\circ} \mathrm{C} \& 75 \% \mathrm{RH}\right)$ for three days to determine the shelf life weight loss percentage (related to the initial cluster weight). Ten berries per cluster were separated and, berry firmness was measured in gram force (gf) using hand dynamometer model FDP1000 with a thump (1mm), also the berry removal force was measured in (gf) using the same apparatus. Data of berry firmness and removal force were transformed into Newton units using standard factor (1 gram force $=0.00980665$ Newton). Shattering was determined by given two light shakes by hand for every cluster in sample. The shattered berries were weighed. Shattering was calculated by dividing the shattered berries weight by cluster weight before the shaking and expressed as percentage. Decayed berries were 
separated, weighted and expressed as percentage per cluster weight. Marketable cluster was recorded and expressed as the percentage of the sound cluster weight without any decayed berries, related to the initial fresh weight before the storage period. Marketable cluster $(\%)=$ (sound cluster weight after storage period/ fresh cluster weight before storage) x 100 .

Berry quality: Soluble solid contents (SSC) of berries juice was measured using the hand refractometer apparatus and expressed as a percent. Titratable acidity was determined as $\mathrm{mg}$ of tartaric acid equivalent using $\mathrm{NaOH}(0.1 \mathrm{~N})$ in $100 \mathrm{ml}$ of berries juice. SSC: acid ratio was calculated. Juice $\mathrm{pH}$ of the berries juice was determined for each replicate and each treatment using Micro Computer $\mathrm{pH}$ version 6071, then the average $\mathrm{pH}$ per treatment was calculated.

\section{Chemical properties}

Pectinmethylesterase activity determination (PME)

Frozen samples of berries (50g) were assayed for PME enzyme activity via a titration technique developed by Anthon and Barrett (2006)

Sugar contents (total, reducing and non reducing sugars) (\%)

Total, reducing and none reducing sugars contents were determined using $80 \%$ ethyl alcohol. The total sugars content was measured as recommended by Dubois et al., (1956).The reducing sugars were determined by Nelson Arsenate Molybdate Colorimetric method according to Malik and Singh (1980). The nonreducing sugars content was calculated by the difference between total sugars and reducing sugars.

\section{Cluster total qualities index}

To get a general proper meaningful value of the determined quality parameters, cluster total quality index was calculated according to El-Abbasy (2006). This was calculated as a sum of the absolute units for the values of SSC: acid ratio, marketable clusters (MC), berry firmness (F) and berry removal force (RF). The absolute unit of value was calculated by dividing the measured parameter value by the highest recorded value for the same parameter in the same season. The author supposed that the cluster overall quality index equal: [(25\% SSC: acid ratio + 25\% (MC) + 25\% (F) + 25\% (RF)) /4]

\section{Statistical analysis}

Analysis of variance method as split plot design according to Snedecor and Cochran (1972), and means were compared by DMRT according to Duncan (1955).

\section{Physical properties}

\section{Results and Discussion}

Cluster weight loss (\%)

Cluster weight loss during cold storage and shelf life were consistently higher in $\mathrm{CaCl}_{2}$ treatment than those of the other treatments (Table 1). The loss in cluster weight is proportionally increased with the storage period increased. 
Cluster weight loss showed negative correlations with berry firmness, removal force and titratable acidity (Table 4). These results are confirmed by CarvajalMillán et al. (2001) and Zoffoli et al. (2009).

\section{Berry firmness, removal force and shattering}

Clusters treated with $\mathrm{GA}_{3}+\mathrm{CaCl}_{2}$ and $\mathrm{GA}_{3}+\mathrm{CPPU}+\mathrm{CaCl}_{2}$ had significantly higher berry firmness and berry removal force during the two seasons, respectively followed by clusters treated with $\mathrm{GA}_{3}+\mathrm{CPPU}$ (Table 1 ). The lowest value was obtained with control treatment during the both seasons. Data showed that, grapes firmness was reduced as cold storage period increased, where the highest firmness was recorded at zero time of storage followed by 15 days of cold storage period and the lowest firmness was noticed after 60 days cold storage period. Berry firmness and removal force showed negative correlations with PME activity (-0.81 and -0.89 , respectively) (Table 4$)$. Significantly the lowest value of berries shatter was showed with $\mathrm{GA}_{3}+\mathrm{CPPU}+\mathrm{CaCl}_{2}$ treatment. Data cleared the increasing of berry shatter with the increasing of storage periods and the lowest value was showed at zero storage time. Berries shatter showed a positive correlation with pectinmethylestrase (PME) activity (0.75). These results are in harmony with Chervin et al. (2009) and Zabadal and Martin (2006). The increase in firmness is ascribed to increased cell turgidity as sugar and potassium are downloaded in the berries, stimulating water uptake driven by osmotic pressure of the berries. Since water loss occurs during cold storage, the decrease in berry firmness is ascribed to water loss, resulting in less turgid vacuoles of cells. Moreover, pre-harvest $\mathrm{Ca}$ treatments used to increase $\mathrm{Ca}$ content of the cell wall was effective in delaying senescence, resulting in firmer and higher fruit quality (Raese and Drake 2008). Spraying $\mathrm{GA}_{3}$ after fruit set enhanced the number of epidermis and hypodermal layers in berry skin and increasing the diameter, thickness of bark and diameter of wood cylinder of the berry pedicel (Rizk-Alla et al., 2011). Marzouk and Kassem (2011) concluded that, spraying calcium chloride resulted in, berry adherence strength increased.

\section{Berry decay (\%) \\ Marketable fruits (\%)}

The lowest marketable clusters were obtained with the control treatment (Table 1) 98.45 and $97.62 \%$ ) compared with the other treatments, in both seasons, respectively. Significantly high percentage of marketable fruits was noticed after 30 days of storage period, and the lowest percent was showed after 60 days of storage period. Marketable fruits showed pronounced negative highly correlation with clusters weight loss (-1.00) (Table 4). Marzouk and Kassem (2011) reported that $\mathrm{GA}_{3}$ and cytofex (CPPU) sprayed on "Thompson seedless" grapes at two stages of berry development, pea stage (4 $-5 \mathrm{~mm}$ fruit diameter) and vèraison stage reduced the percentage of unmarketable fruits. 


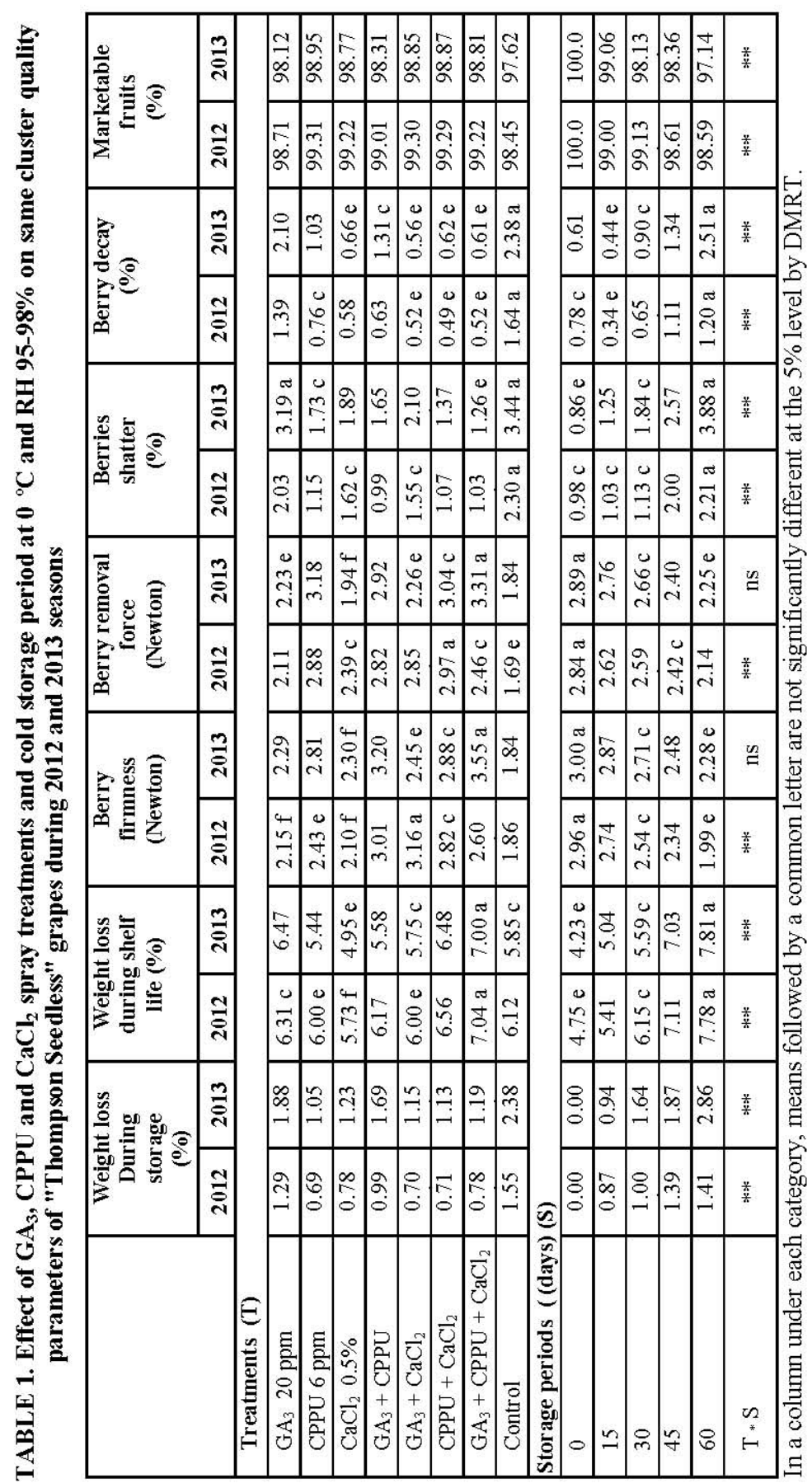

Egypt. J. Hort. Vol. 42, No. 1 (2015) 


\section{Berry quality}

Table 2 showed higher SSC: acid values of control and $\mathrm{CaCl}_{2}$ treatments compared to the other treatments. Data showed that, SSC: acid ratio generally increased as the storage period increased. After 60 days of cold storage, clusters scored statistically the highest value in the two seasons. On contrary 15 days, stored fruits scored the lowest values. This low value reflected to higher SSC $\left(\mathrm{R}^{2}\right.$ $=0.75)$ and low titratable acidity $\left(\mathrm{R}^{2}=-0.84\right)$. The decreasing in SSC: acid ratio of all growth regulators and its combination as compared to control and $\mathrm{CaCl}_{2}$ treatments could be explained according the results of Deng et al. (2006) who reported that, clusters of Kyoho grapes (Vitis vinifera X V. labrusca) sprayed with $\mathrm{GA}_{3}$ as a pre-harvested treatment delayed the increase of soluble solids content (SSC) at $0^{\circ} \mathrm{C}$ in $95 \%$ relative humidity for 60 days, and Nilnond and Labantao (2010) who concluded that, $\mathrm{GA}_{3}$ mixed with CPPU tended to produce the higher percent of berry acidity. The increment in titratable acidity may reflecting a late maturation of berries on treated vines as shown by Ezzahauani (2000) on Perlette grape cv. Gibberellic acid $\left(\mathrm{GA}_{3}\right)$ at $50 \mathrm{ppm}$ mixed with CPPU at $5-10 \mathrm{ppm}$ tended to produce the highest percent of berry acidity (Nilnond and Labantao, 2010). Also Smith (2008) on 'Merlot clone 181' grape vines and Strydom (2013) on some grape cultivars, concluded that applications of forchlorfenuron (CPPU) during different flowering stages resulted in increase in fruit titratable acidity. The highest values of berry juice $\mathrm{pH}$ were observed with $\mathrm{GA}_{3}+\mathrm{CPPU}+\mathrm{CaCl}_{2}$ treatment during both seasons (Table 2). The berry juice $\mathrm{pH}$ generally was slightly affected by the storage period especially in the first season. After 60 days of cold storage, clusters scored statistically the highest value. On contrary 15 days stored fruits scored the lowest values.

\section{Pectinmethylestraese activity (PME) (unit/h)}

Data in Table 2 clear that, the clusters of control treatment had the highest PME activity (Table 2) followed by that treated with $\mathrm{GA}_{3}$ and $\mathrm{GA}_{3}+\mathrm{CaCl}_{2}$. However, the lowest PME activity was showed with CPPU treatment and its combinations (CPPU, $\mathrm{GA}_{3}+\mathrm{CPPU}, \mathrm{CPPU}+\mathrm{CaCl}_{2}$ and $\mathrm{GA}_{3}+\mathrm{CPPU}+\mathrm{CaCl}_{2}$ ). PME activity gradually increased with advancing storage periods during two seasons. Significantly, the highest PME activity was observed after 60 days followed by that after 45 days of cold storage while, the lowest value was noticed after 15 days of storage. 


\section{Sugars content}

The present treatments showed different affects on total, reducing and non reducing sugars contents in the two seasons. The higher value was obtained with $\mathrm{CaCl}_{2}$ treatment (Table 3) and the lowest value was obtained in clusters of $\mathrm{GA}_{3}+\mathrm{CPPU}+\mathrm{CaCl}_{2}$ treatment in the first season. By the second sea the clusters of control showed significantly the highest value. However, the lowest value was obtained with CPPU and $\mathrm{GA}_{3}+\mathrm{CPPU}+\mathrm{CaCl}_{2}$ treatments. Total and reducing sugars contents generally increased, whereas non-reducing decreased as the cold storage period increased in the two seasons. After 60 days cold stored clusters scored statistically the highest value in the two seasons. Statistically, the lowest values of total and reducing sugars contents during storage were noticed after 15 days of cold storage during the two seasons. Rusjan (2010) studied the eventual impacts of the $\mathrm{GA}_{3}$ application at 20 and $50 \mathrm{ppm}$ on grapevine (Vitis vinifera L.) varieties 'Cardinal' and 'Michele Palieri', on grape storage potential and concluded that, the statistically highest total sugar concentration was determined at $50 \mathrm{ppm}$. $\mathrm{GA}_{3}$ treatments at 25 to $75 \mathrm{ppm}$, applied on bunch at full bloom, significantly reduced sugar contents of "Kishrnish Charni' grapes. The reducing sugar content was observed following treatment with $\mathrm{GA}_{3}$ at 75 ppm (Khan et at., 1996).

\section{Cluster total quality}

The highest value of cluster total quality was obtained with $\mathrm{GA}_{3}+\mathrm{CaCl}_{2}$ treatment, whereas, the lowest value was obtained in clusters of control in the first season (Table 3). By the second season, clusters treated with CPPU, $\mathrm{CPPU}+\mathrm{CaCl}_{2}$ and $\mathrm{GA}_{3}+\mathrm{CPPU}+\mathrm{CaCl}_{2}$ treatments showed significantly the highest values, whereas the lowest values were obtained with $\mathrm{CaCl}_{2}$ and control treatments. Cluster total quality was decreased as the storage period increased. The lowest value was noticed after 60 days of cold storage in both seasons, and the highest values were noticed after 15 days of storage in the first season. In the second season, the differences among 15, 30 and 45 days of cold storage were not significant. Cluster total quality showed positive correlation with some cluster quality parameters (Table 4) such as, berry removal force (0.95) and berry firmness (0.94), marketable fruits (0.64), and negative correlation with fruit decay $(-0.69)$, shatter $(-0.73)$, total sugar $(-0.60)$, non reducing sugar $(-0.53)$ and SSC (-0.66). 
EFFECT OF GIBBERELLIC ACID, CYTOFEX, AND CALCIUM CHLORIDE ... 435

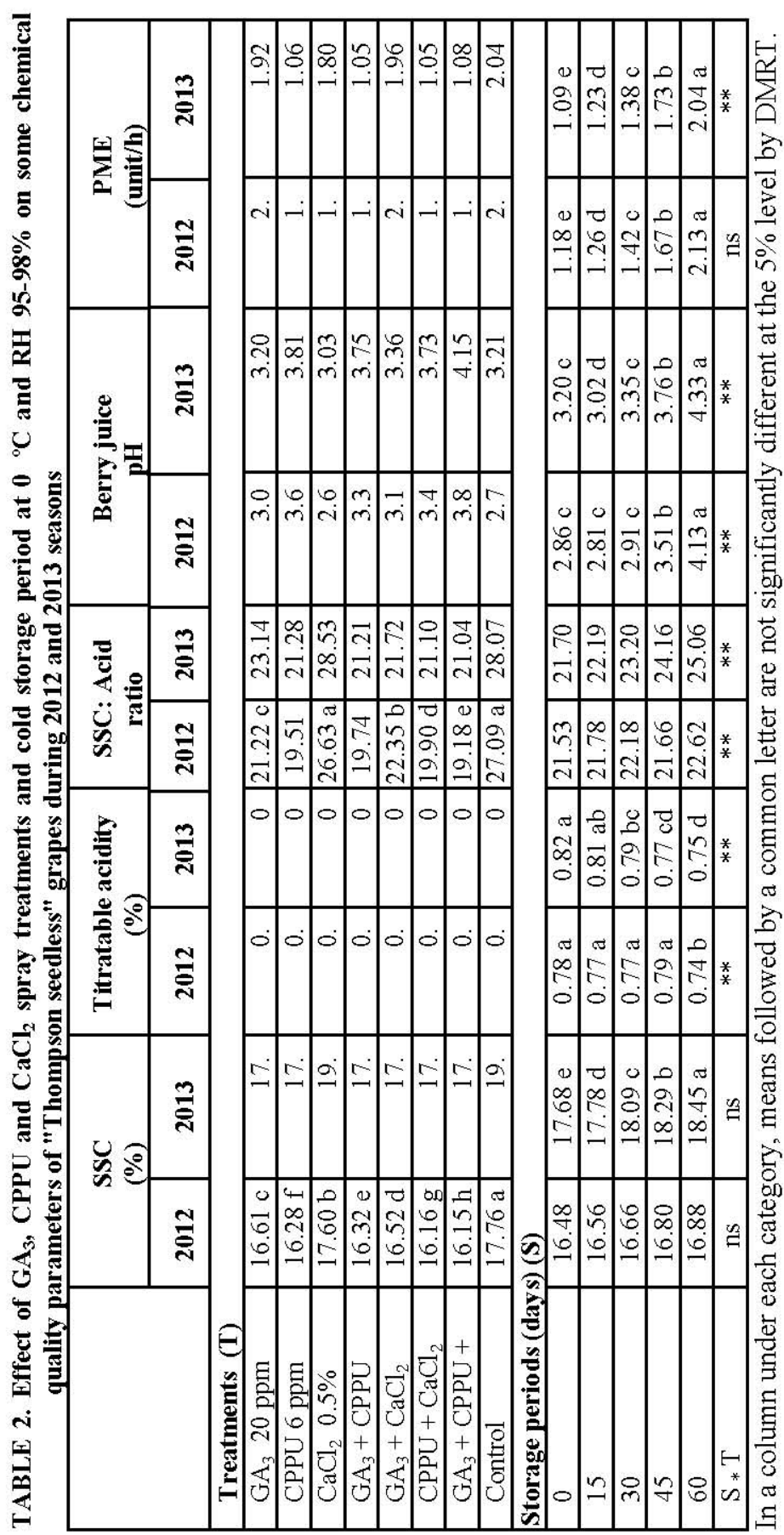

Egypt. J. Hort. Vol. 42, No. 1 (2015) 


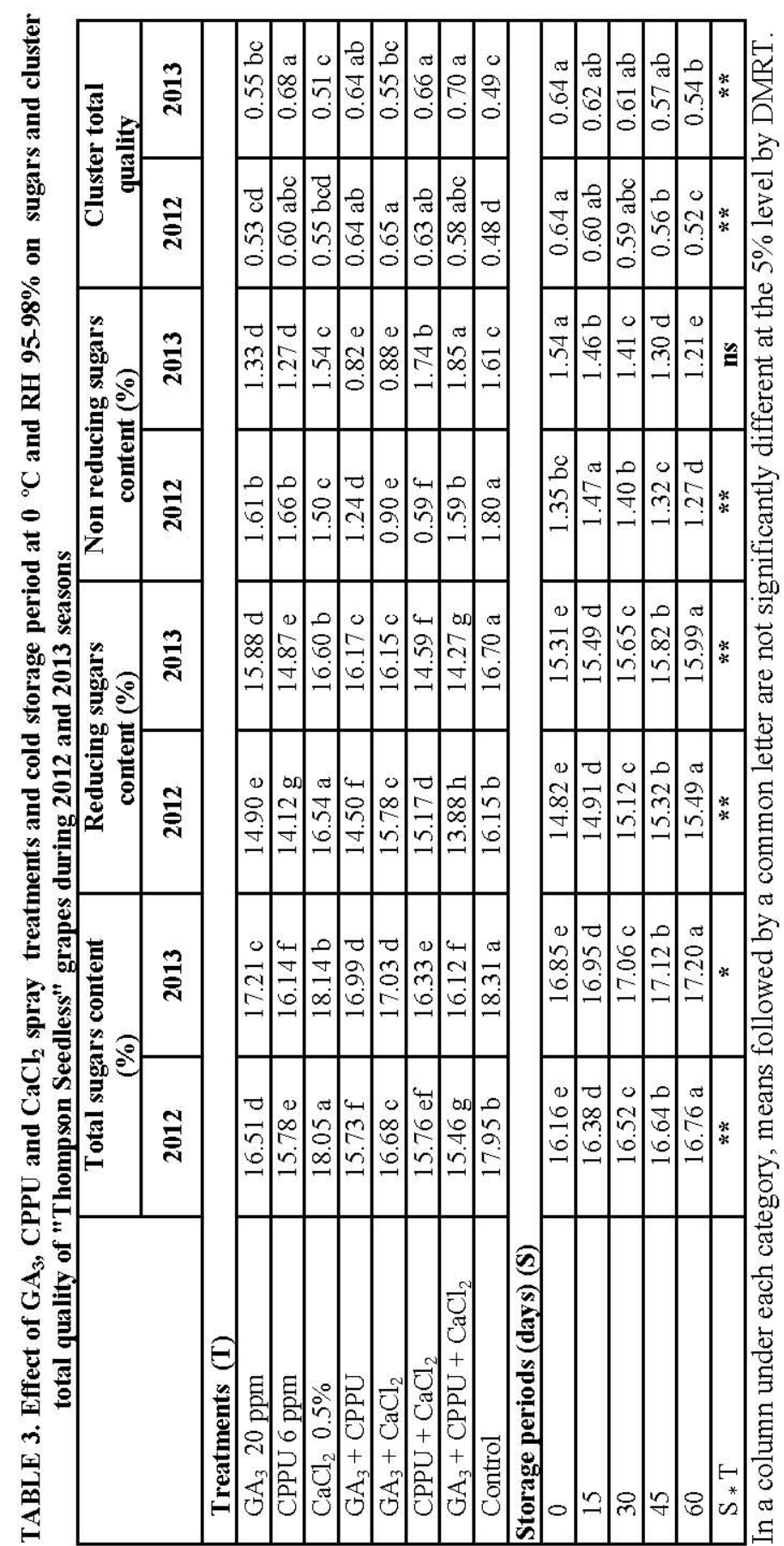

Egypt. J. Hort. Vol. 42, No. 1 (2015) 
EFFECT OF GIBBERELLIC ACID, CYTOFEX, AND CALCIUM CHLORIDE ... 437

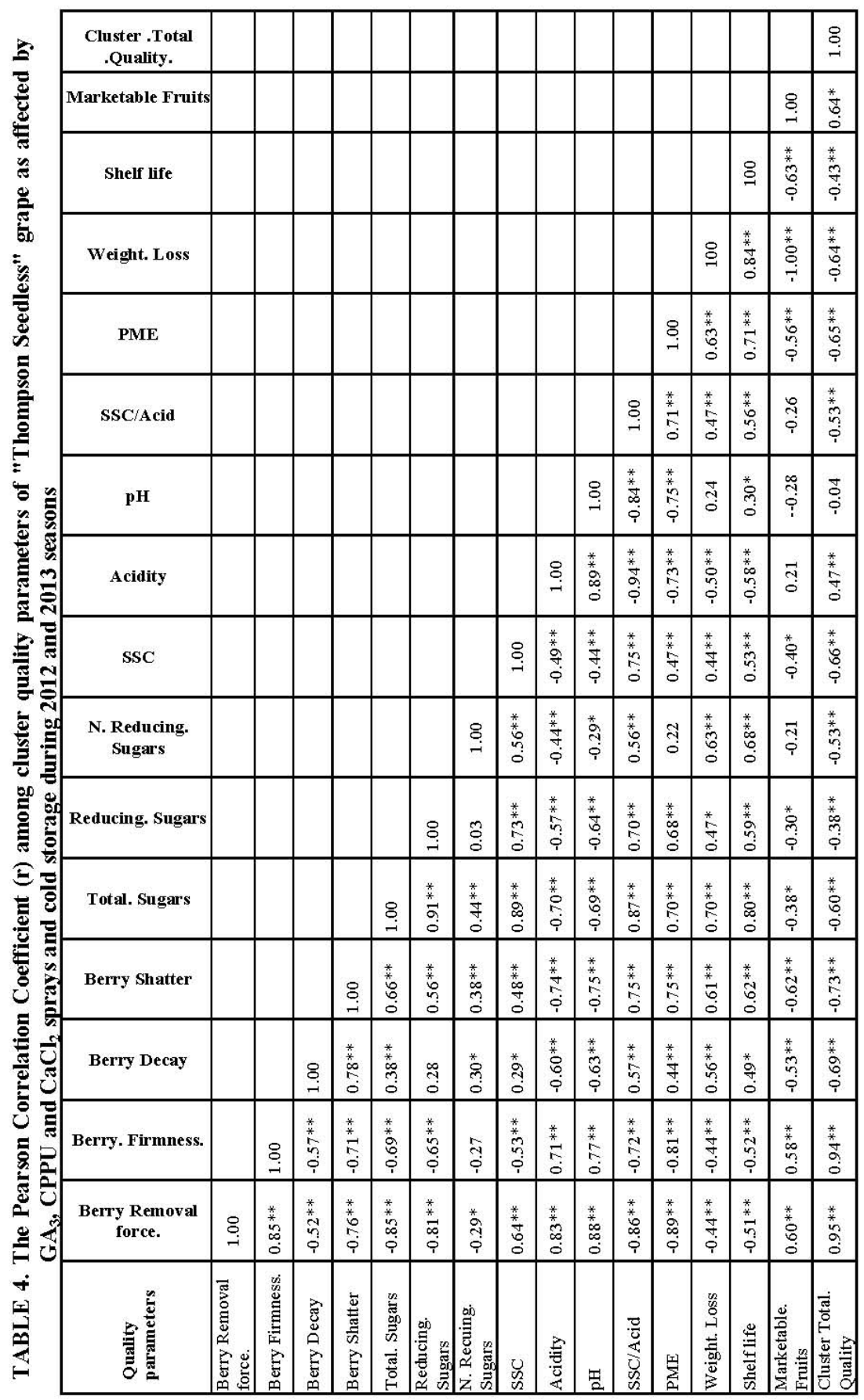

Egypt. J. Hort. Vol. 42, No. 1 (2015) 


\section{References}

FAO (2011) Production Year Book, Rome. Food and Agriculture Organization (FAO), 52, 146 .

Anthon, G.E. and Barrett, D.M. (2006) Characterization of the Temperature Activation of Pectin Methylesterase in Green Beans and Tomatoes. J. Agric. Food Chem., 54, 204-211

Carvajal-Millán, E., Carvallo, T., Orozco, J.A., Martinez, M.A., Tapia, I., Gurrero, V.M., Rascon-Chu, A., Lamas, L.A. and Gardea, A.A. (2001) Polyphinol oxidase activity color changes and dehydration in table grape rachis during development and storage as affected by N-(2-chloro-1-pyridyl)- N phenyl urea. J. Agric. Food. Chem., 49, 946-961.

Chervin, C., Lavigne, D. and Westercampc, P. (2009) Reduction of gray mold development in table grapes by preharvest sprays with ethanol and calcium chloride. Postharvest Biology and Technology, 54, 115-117.

Ciccarese, A., Stellacc, A.M., Gentilesco, G. and Rubino, P. (2013) Effectiveness of pre- and post-veraison calcium applications to control decay and maintain table grape fruit quality during storage. Postharvest Biology and Technology, 75, 135-141.

Deng, Y., Wu, Y., Li, Y.F., Yang, M.D., Shi, C.B. and Zheng, C.J. (2006) Effects of high $\mathrm{O}_{2}$ pretreatment and Gibberellic acid on sensorial quality and storability of table grapes. Food Science and Technology International, 12 (4), 307-313.

Dubois M., Gilles, K.A., Homilton, J.K., Robers, P.A. and Smith, F. (1956) Colorimetric method for determination of sugars and related substance. Anol. Chem., $\mathbf{2 8}$ (3), 350-458.

Duncan, D. B. (1955) Multiple range and multiple F. Test. Biometries, 11, 1-42.

Ebisuda, N.C. and Dokoozlian, N.K. (2003) Forchlorfenuron and ethapon interact on the berry growth and color development of Flame Seedless Table Grapes. ASEV 54th Annual Meeting, Reno, Nevada, June 2003.

El-Abbasy, U.K. (2006) Extending marketing window of Thompson seedless grapes by synthetic cytokinin and naphthalene acetic acid preharvest spray treatments and cold storage. J. Agric. Res. Tanta Univ., 32(3), 662-674

Elad, Y. and Kirshner, B. (1992) Calcium reduces Botrytis cinerea damage to plants of Ruscus hypoglossum. Phytoparasitica, 20, 285-291.

Elad, Y. and Volpin, H. (1993) Reduced development of grey mould (Botrytis cinerea) in bean and tomato plants by calcium nutrition. Journal of Phytopathology, 139, 146-156.

Ezzahauani, A. (2000) Effect of forchlorfenuron(CPPU) and girding on table grape cultivars (perlette) and (Italia). Jouranal - International - des - Sciences - de - la vigne - et - ou-vin., 34 (2), 57 - 60.

Khan, F.U., Khan, F.A. and Zaidi, P.H. (1996) Effect of gibberellic acid $\left(\mathrm{GA}_{3}\right)$ on the chemical composition of Kishmish Charni grape. Agricultural Science Digest, 16, 68-70.

Egypt. J. Hort. Vol. 42, No. 1 (2015) 
Kubik, M., Michalczuk, L. and Malinowski, T. (1991) Does externally applied calcium on endogenous calcium accumulation in apple fruit. Fruit Science. Reports, 18, 7-16.

Malik, C.P. and Singh, M.B. (1980) "Plant Enzymology and Histoenzymolgy", A Text Mannual. Kalyoni Publishers, New Delhi, India, p. 286.

Marzouk, H.A. and Kassem, H.A. (2011) Improving yield, quality, and shelf life of Thompson seedless grapevine by preharvest foliar applications. Postharvest Biology and Techology., 130 (2), 425-430.

Meena, V.S., Nambi, V.E., Vishawakarma, R.K., Gupta, R.K. and Nangare, D.D. (2012) Effect of Gibberellic acid on fruit quality and storability of grape in semi-arid region of Punjab. Agriculture Science Digest, 32(4), 344-356.

Navarro, M., Retamales, J. and Defilippi, B. (2001) Efecto del arreglo de racimo y aplicación de citoquinina sintética (CPPU) en la calidad de uva de mesa variedad sultanina tratada con dos fuentes de giberelinas. Agric. Tec. (Chile) 61, 15-25.

Nilnond, S. and Labantao, C. (2010) $\mathrm{GA}_{3}$ and CPPU application to increase berry size of 'Perlette' table grape. Thailand Research. Fund, Bangkok, 31(4), 538-544.

Raese, J.T. and Drake, S.R. (2008) Effects of preharvest calcium sprays on apple and pear quality. Journal of Plant Nutrition, 16 (9),1807-1819.

Retamales, J., Bangerth, F., Cooper, T. and Callejas, R. (1995) Effect of CPPU and $\mathrm{GA}_{3}$ on fruit quality of Sultanina table grape. Acta Hortic., 394, 149-157.

Reynolds, A.G., Wardle, D.A., Zurowski, C. and Looney, N.E. (1992) Phenylureas CPPU and thidiazuron affect yield components, fruit composition and storage potential of four seedless grape selections, J. Amer. Soc. Hort. Sci., 117 (1), 85-89.

Rizk-Alla, M.S., Abd El-Wahab, M.A. and Fekry, O.M. (2011) Application of $\mathrm{GA}_{3}$ and NAA as a means for improving yield, fruit quality and storability of black Monukka Grape Cv. Nature and Sci., 9 (1),1-19.

Rusjan, D. (2010) Impacts of gibberellin $\left(\mathrm{GA}_{3}\right)$ on sensorial quality and storability of table grape (Vitis vinifera L.). Acta agriculturae Slovenica, 95 (2),163 - 173

Smith, D.S. (2008). Effects of Timing of CPPU Applications on Rabbiteye Blueberries. Hortscience, 43 (5),1446-1448.

Snedecor, G.W. and Cochran, W.G. (1972) "Statistical Methods", $6^{\text {th }}$ ed. Iowa State Univ. Press. Amsterdam.

Strydom, J. (2013) Research Note: Effect of CPPU (N-(2-Chloro-4-Pyridinyl)-N'Phenylurea) and a seaweed extract on Flame Seedless, Redglobe and Crimson Seedless Grape Quality. S. Afr. J. Enol. Vitic., 34 (2), 55-59

Vial. P., Crisosto, C. and Crisosto, G. (2005) Early harvest delays berry skin browning of Princess table grape. Calif. Agric., 59, 103-108. 
Wafaa, A. Abd-Elwahab, Abd-Elwahab, M.S. and Kamel, O.T. (2014) Using safe alternatives for controlling postharvest decay, maintaining quality of Crimson Seedless grape. World Applied Science, 31(7), 1345-1357.

Zabadal, T.J. and Martin, J.B. (2006) Effect of CPPU on fruit development of selected seedless and seeded Grape cultivars. Hortscience, 41(1), 154-157.

Zabadal, T.J. and Bukovac, T.W. (2006) Gibberellic acid sprays increase berry size and reduce shot berry of 'Vanessa' grapevines. Journal of American. Pomological. Society, 54, 130-133.

Zoffoli, J. P., B. A. Latorre and P. Naranjo (2009) Preharvest applications of growth regulators and their effect on postharvest quality of Table Grapes during cold storage. Postharvest Biology and Technology, 51(2), 183-192.

(Received 5/10/2014; accepted 5/ 2 /2015)

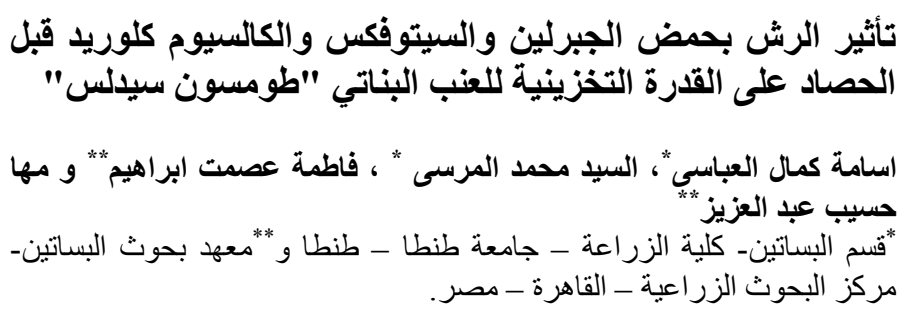

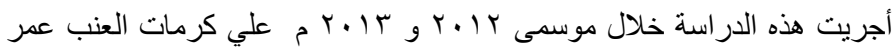

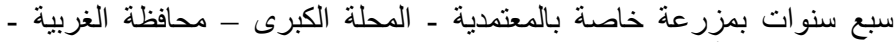

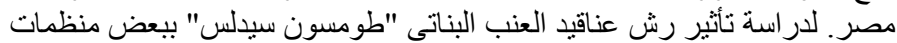

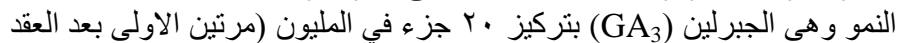

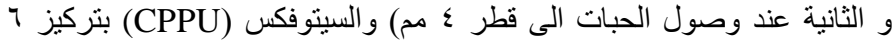

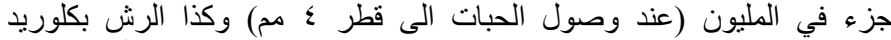

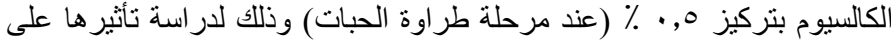

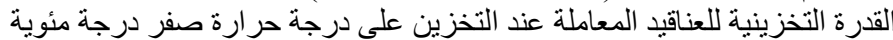

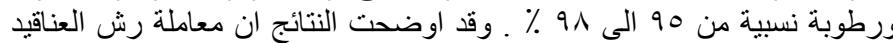

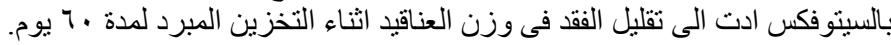

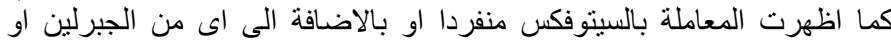

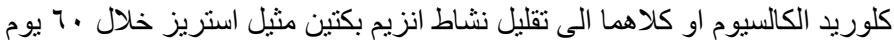

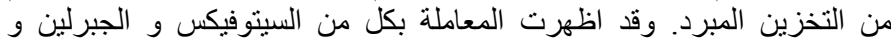

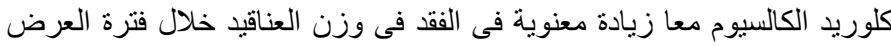

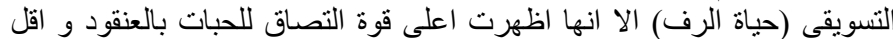

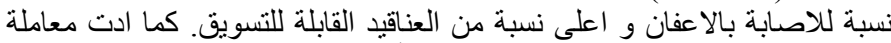

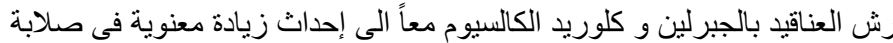

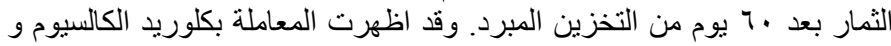

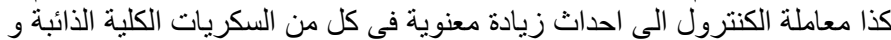

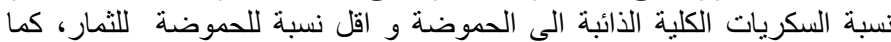

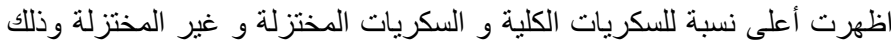
بعد · ب يوم من التخزين المبرد.

Egypt. J. Hort. Vol. 42, No. 1 (2015) 